
and Allied Sciences (IJBPAS) 'A Bridge Betuen caboratory and QRendo'

www.ibpas.com

\title{
LAND USE IN EAST VIDARBHA
}

\section{DANDEKAR DB* AND LAKHE VN}

Chattraveer Raje Sambhaji, Public Administrative College, Morwa, Dist - Chandrapur.

\author{
S. P. College, Chandrapur
}

*Corresponding Author: Dr. Deepali B. Dandekar: E Mail: deepalidandekar12@gmail.com

Received $10^{\text {th }}$ June 2021; Revised $11^{\text {th }}$ July 2021; Accepted $20^{\text {th }}$ Aug. 2021; Available online $15^{\text {th }}$ Jan. $_{2022}$

https://doi.org/10.31032/IJBPAS/2022/11.1.1009

\section{ABSTRACT}

Agriculture in east vidarbha dates back to the latter parts of harappan clearly that's on the whole the land use pattern has remained more are less. Agriculture is largest economics sector and play a very significant role in the socio-economic development of our country. The use of land by man depends on the qualities of land that he lives on where the land is fertile and flat the climate is favourable for the cultivation of crops agriculture is followed.

Since the beginning of human existence man has directed his activities with reference to earth resources and he knows how to use for his own benefit. A tract of land is defined geographically as a specific area of the earth's surface. How every state has potential for growth in agricultural sector in spite of changes.

In Maharashtra 36 district, 355 blocks and 43,656 villages population 11.24crores is that means Maharashtra is $3^{\text {rd }}$ largest state in India Maharashtra. State contribution of nominal GDP growth $14.4 \%$. The highest occupation sector of agriculture in that sector $365 \%$ population included in agriculture area.

For the present short research study statistical and cartographical technique use for annual variation data. (1990-2020). The present study totally depend on figure, obtain of government of Maharashtra subversion and used meteorology find by conclusion.

Keywords: Resources, dwelling, production, economic, Land Use, crop cultivation

INTRODUCTION:-

The available land resources of any country exercise a tasting effect on the economic life of man or nation. Indirectly 
the available land resources affect the economic life because the production of raw material is dependent on the nature of landscapes. Land is basis of economic activities and the prime resource for man. Since the beginning of human existence man has directed his activities with reference of resource and he knows how to use for his own benefit. A tract of land is defined geographically as a specific area of the earth surface. The term land actually has different meaning in different subjects for a demographer it is the dwelling place of population but for a geographic earth is as a home of a man.

\section{OBJECTIVE:-}

The main objective behind presenting the short research paper is a follows -

1. To study the changes in agricultural land use pattern in eastern vidarbha.

2. To highlight difference in land utilization in east vidarbha.

\section{Methodology and Data Base :-}

The present study totally depends upon the figures that have been obtained from the Government offices and Maharashtra mahadesh website. This data is collected from statistical department of chandrapur. For the present short research study statistical and cartographical technique is used for this. Annual data of

\section{STUDY REGION:-}

East Vidarbha region has been selected for study to highlight. The deference in land utilization changes in land pattern can be very clearly seen more of the forestland has been cut for agricultural and industrial area.

The east vidarbha is located in the east part of Maharashtra state lies between $18^{0} 2^{\prime}$ to $20^{\prime} 2^{\prime \prime} \mathrm{N}$ latitude and $70^{\circ} \mathrm{E}$ to $81^{\circ}$ 2' east longitudes. To the north and east of it line the Madhya Pradesh state and west the Amrawati and Yawatmal. To its south line the state of Andhra Pradesh. The area of East vidarbha is 51377 sq. $\mathrm{km}$ and population has increased to a greaterrate hence keeping this point in view the region is selected for study purpose. Socioeconomics and cultural development is needed in this region east vidarbha comes in a Deccan Trap. Where igneous rock of granite type is of found agricultural is not much developed her because of lack of irrigation facilities. land utilization from year 1991 to 2011 is used by study.

\section{CLIMATE :-}

Climate influence the economics activities of a region. The climate here is divers. Different and district one. It is of monsoon type. The seasonal variations are found here is the average and annual distribution of temperature and rainfall. 


\section{TEMPERATURE :-}

Normally it is seen that the temperature of east vidarbha is high in the months of March, April and May low in the months of October, November and it can be seen that maximum temperature is found is chandrapur and Bhandara Dist. i.e. nearly $47.7^{\circ} \mathrm{c}$ to $47.5^{\circ} \mathrm{c}$ respective whereas lowest recorded temperature can be seen in Nagpur.

December for the following tubule of 2001

Table 1: Maximum and Minimum Temperature of east vidarbha (2001)

\begin{tabular}{|c|c|c|c|c|}
\hline Sr. No. & District & Max. Temp. ${ }^{0} \mathrm{C}$ & Min. Temp. ${ }^{0} \mathrm{C}$ & Average \\
\hline 1 & Nagpur & 46.8 & 6.6. & 26.7 \\
\hline 2 & Wardha & 46.6 & 6.4 & 26.55 \\
\hline 3 & Bhandara & 47.5 & 7.2 & 27.40 \\
\hline 5 & Chandrapur & 47.7 & 7.0 & 27.4 \\
\hline
\end{tabular}

(Ref. for costing dept. of climatology in Nagpur daily report page No. 23)

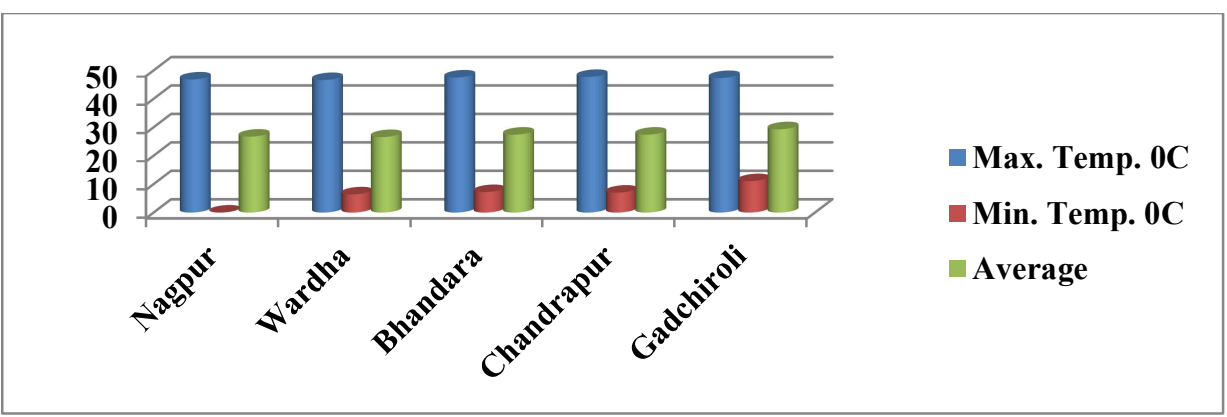

Figure 1: Maximum and Minimum Temperature of east vidarbha (2001)

\section{RAINFALL:-}

South west mansoon blow in the first week of June giving rains to this region. Chandrapur, Bhandara and
Gachiroli receive highest rainsie. 1561.96 $\mathrm{mm}$ to $1540 \mathrm{~mm}$ respectively whereas Nagpur has very less rains.

Table 2: Annual Average Rainfall in $\mathrm{mm}$

\begin{tabular}{|c|c|c|}
\hline Sr. No. & District & Rainfall in $\mathbf{~ m m}$ \\
\hline 1 & Nagpur & $\mathbf{9 8 3}$ \\
\hline 2 & Wardha & $\mathbf{1 0 8 3}$ \\
\hline 3 & Bhandara & 1540 \\
\hline 4 & Chandrapur & 1255 \\
\hline 5 & Gadchiroli & 1561.96 \\
\hline
\end{tabular}

(Ref. Example for costing dept. of pune)

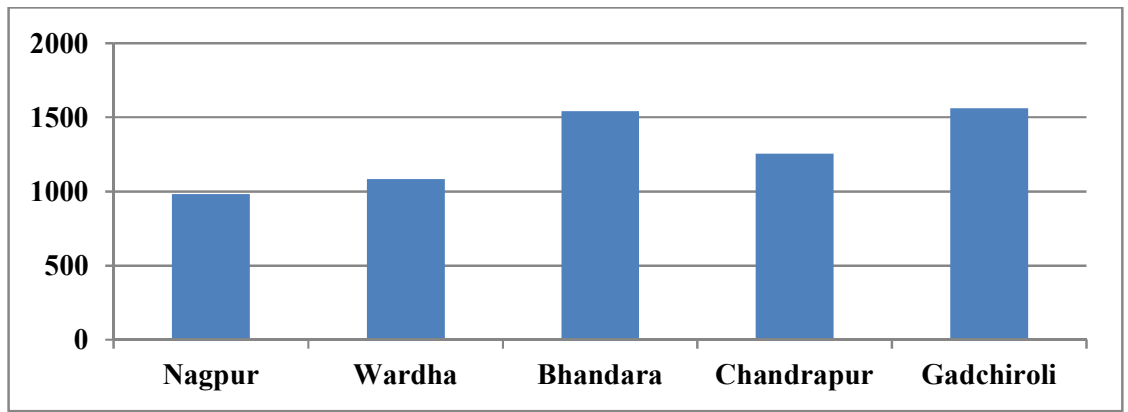

Figure 2: Annual Average Rainfall in mm 
SOIL :-

The soil found here is classified into six types. They are as follows.

1. Medium black soil

2. Reddish brown soil

3. Brown grey

4. Alluvial soil

\section{LAND USE IN EAST VIDARBHA :-}

The use of land by man depends on the qualities of land that he lives on where the land is fertile and flat and the climate is favourable for the cultivation of crops agriculture is followed.
5. Deep Black soil

6. Laterite soil

The weathering and erosive processes disintegrate the rocks farming small particles of soil. The soil farming process is mainly influenced by the parent rock climate vegetation and animal life.

Forman (T. W. 1968):- " Land use is also related to conservation of land from one major use to another general use." Land use to means surface utilization of all developed and vacant land and for a specific point at a given time and space.

Table 3: Percentage Of Land Utilization In East Vidarbha Land Use (2001 To 2011) Are In 00 Hectores

\begin{tabular}{|c|c|c|c|c|c|}
\hline Sr. No. & Land Use & 2001 Area & Percentage & 2011 Area & Percentage \\
\hline 1 & Area Under Forest & 20316 & 39.62 & 19428 & 38.03 \\
\hline 2 & $\begin{array}{c}\text { Non Agricultural use Barren land } \\
\text { uncultivable land }\end{array}$ & 4016 & 7.83 & 4465 & 8.70 \\
\hline 3 & $\begin{array}{c}\text { Permanent pastures grazing land tree } \\
\text { crops and grooves }\end{array}$ & $\mathbf{5 2 4 4}$ & 10.22 & 4361 & 8.59 \\
\hline 4 & Follow land & 1512 & 2.94 & 1426 & 2.78 \\
\hline 5 & Total cropped area & 20178 & 39.35 & 21506 & 41.94 \\
\hline
\end{tabular}

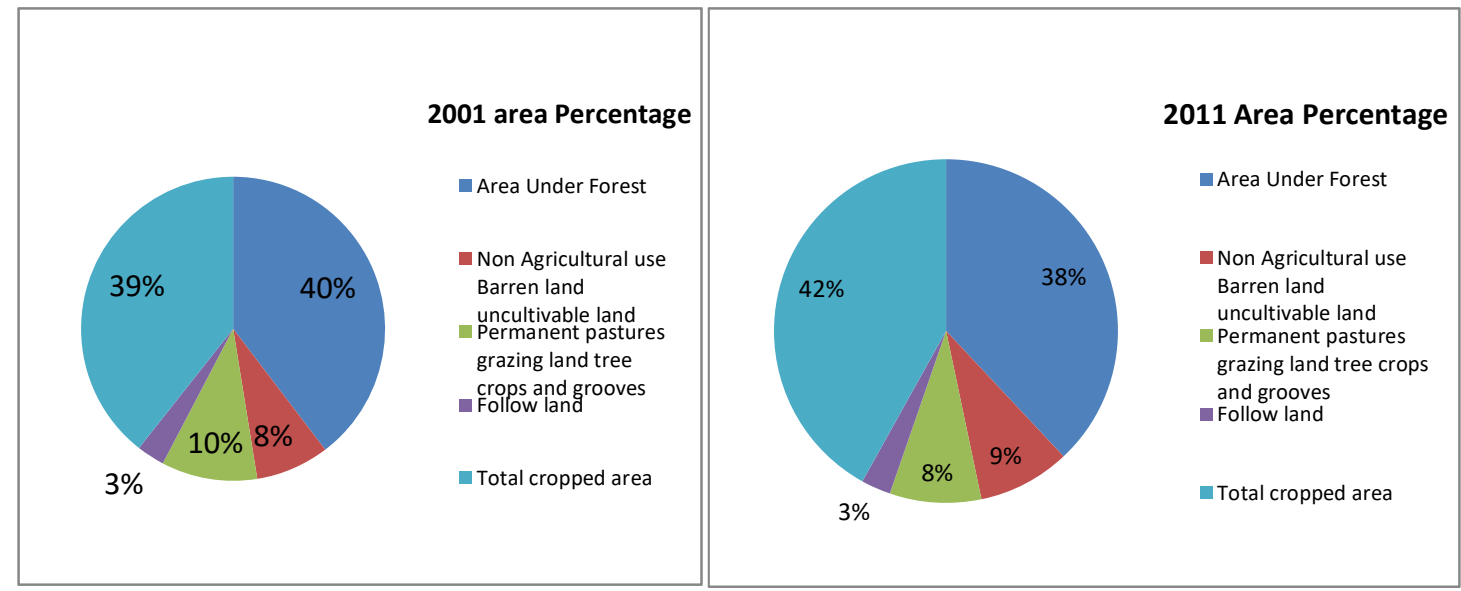

Table 3: Percentage Of Land Utilization In East Vidarbha Land Use (2001 To 2011) Are In 00 Hectores 
The Figures 3 and Table 3 and show that there is a change I land utilization in east vidarbha. The total geographical area is 51266 hectors. The area under forest in 2001 is nearly $38.62 \%$ compared to 2011 it has come down to $38.03 \%$ it means that the percentage of forest has decreased by $0.82 \%$ which is a matter of great concern, at the me time the total cropped area has increased from $39.35 \%$ to $41.94 \%$ it shows that pastures land grazing land are being used for this. It also denotethat because of tremendous increase in population of follows land has also decreased from $2.94 \%$ to 2.75 $\%$ It we try to make a comparative study to the data from 2001 to 2011 of land use then we find some changes in it.

The main used of land comes under the class of forestry, grazing and agricultural. In respect to the total geographical area we can see that the area under forest us constantly decreasing. The reasons may be varied for selfish gains forest have been destroyed tremendously. They are under forest is insufficient and has to be increased.

\section{CONCLUSION:}

The main conclusion which emerges from the above analysis of the pattern of land utilization and changes in East Vidarbha is that without present method of land use the available area is very insufficient for our needs.

1. While studying the crop pattern of each district of east vidarbha it is observed that socio-economic and geographical factors are more dominant.

2. Subsistence agriculture is the main characteristic of Vidarbha the production of crops.

3. Because of Industrial growth in Ngapur and Chandrapur temperature has increased while the amount of rainfall has decreased resulting ecological Imbalance.

\section{RENEDIES:-}

The whole study of subject is showing that east vidarbha is a most important part of Maharashtra it is very neccy part of zone by will be use a most comp of east zone land use pattern.

\section{REFERENCE:-}

[1] Agriculture Growth in India Land use pattern Book - Dr.Ramayan Prasad, New Delhi

[2] Conversion of Agricultural land for - Sai Publication, Pune

[3] Census of India 1961, 1971, 1981, 1991, 2011 Chandrapur District and Vidarbha.

[4] Rural Settlement types in U.P - Ahmed E [5] https://en.wikipedia.org/wiki/Vidarbha 